\title{
Sistem Visualisasi Polaradiasi Antena Memanfaatkan Mikrokontroller Sebagai Pengendali Antena Penerima (Rx)
}

\author{
Akuwan Saleh \\ Electrical Engineering Polytechnic Institute of Surabaya (EEPIS), \\ Institut Teknologi Sepuluh Nopember (ITS), Surabaya, Indonesia \\ Kampus ITS Keputih Sukolilo, Surabaya, 60111 \\ Telp. +62 (31) 5947280 Fax +62 (31) 5946114 \\ E-mail: akuwan@eepis-its.edu
}

\begin{abstract}
Abstrak
Pola radiasi merupakan salah satu parameter antena yang sangat penting untuk diketahui dan difahami oleh mahasiswa jurusan teknik telekomunikasi pada khususnya dan mahasiswa politeknik pada umumnya. Oleh karena itu pada mata kuliah praktek antena, pengukuran pola radiasi sangat diutamakan. Proses pengukuran pola radiasi antena selama ini dilakukan secara manual, dimana resolusi pengambilan data yang dapat dilakukan minimum $10^{\circ}$ sehingga hasil penggambaran pola radiasi kurang akurat.

Pada paper ini telah dilakukan penelitian tentang pembuatan sistem interfacing yang digunakan untuk pengatur putaran antena penerima dan pengambilan data oleh spectrum analyzer secara otomatis. Sistem ini dapat diset dengan resolusi minimum 0,6 $6^{\circ}$ an sekaligus melakukan penggambaran pola radiasi menggunakan software yang ditampilkan pada monitor personal komputer (PC). Hardware pada sistem ini menggunakan mikrokontroller sebagai pengendali gerakan antena, kabel RS 232 untuk komunikasi serial antar spectrum dan komputer, pengiriman dan pengambilan data oleh spectrum analyzer menggunakan kode ASCII, sedangkan visualisasinya dilakukan dengan software visual basic.

Sistem ini diharapkan dapat membantu mahasiswa dalam praktek pengukuran pola radiasi secara otomatis dan dapat membandingkan hasilnya dengan cara manual. Hasil penggambaran pola radiasi secara otomatis, pancaran radiasinya (main loop) terfokus/terarah pada sudut $0^{\circ}$, sedangkan penggambaran secara manual terlihat adanya side loop dan pancaran radiasinya tidak tepat berada pada $0^{\circ}$ yaitu meleset kurang lebih 50. Berdasarkan data tersebut dapat dikatakan bahwa penggukuran menggunakan sistem ini lebih cepat dan akurat dibandingan dengan pengukuran secara manual.
\end{abstract}

Kata kunci : Pola radiasi, Mikrokontroller, Spectrum anlyzer, RS 232, ASCII, Visualisasi

\section{PENDAHULUAN}

Pada proses pengukuran pola radiasi antena secara manual yang selama ini dilakukan untuk praktek mahasiswa, ternyata ditemukan banyak kelemahan yang berpengaruh pada hasil penggambarannya. Hal ini disebabkan karena resolusi pengambilan data yang sangat rendah, penunjukan posisi sudut tidak presisi dan waktu yang digunakan sangat lama sehingga kurang effektif.

Untuk memperbaiki kondisi tersebut, maka dibuat suatu sistem baru yang dapat digunakan untuk melakukan pengukuran pola radiasi antena secara otomatis. Sistem ini terdiri dari penggerak antena penerima secara otomatis yang dikendalikan oleh mikrokontroler dan sekaligus sebagai diinterfacing pada spectrum anlyzer. Pengiriman dan pengambilan data oleh komputer dilakukan dengan kode ASCII melalui kabel RS 232. Resolusi pengambilan data pada sistem ini dapat diset dari komputer secara variasi dengan resolusi minimum $0,6^{\circ}$. Data yang diperoleh dari hasil pengukuran, disimpan pada database yang sudah disediakan pada komputer.
Kemudian data hasil pengukuran dinormalisasi dan penggambaran pola radiasi ditampilakan pada layar monitor menggunakan software visual basic. Dengan sistem ini diharapkan dapat diperoleh hasil pengukuran yang lebih akurat dan waktu yang digunakan lebih cepat dari pada dengan cara manual.

Selain itu hasil penelitian ini diharapkan dapat digunakan sebagai modul praktikum dalam mata kuliah Teknik Antena dengan spesifikasi pada Pengukuran Pola Radiasi Antena.

\section{DASAR TEORI}

Teori penunjang yang diperlukan untuk penyelesaian penelitian ini meliputi : pola radiasi antena, komunikasi data serial, pengaksesan port serial pada visual basic serta komunikasi serial pada spectrum analyzer.

\subsection{Pola Radiasi Antena}

Pengertian dari pola radiasi antenna adalah pernyataan secara grafis yang menggambarkan sifat radiasi dari suatu antenna (pada medan jauh) sebagai fungsi dari arah ( fungsi sudut $=$ Anguler). 
Ditinjau dari cara pengambarannya, pola radiasi dibedakan menjadi dua macam yaitu: pola daya dan pola medan. Pola daya adalah apabila pola tersebut menggambarkan daya dari antenna yang diukur, sedangkan pola medan adalah apabila pola tersebut menggambarkan arah medan listrik dari antena yang diukur. Dalam menyatakan pola radiasi secara grafis dapat digambarkan pola dalam bentuk absolute atau dalam bentuk relatif. Bentuk relatif adalah bentuk pola yang sudah di normalisasikan yaitu setiap harga dari pola radiasi tersebut telah dibandingkan dengan harga maksimumnya.

Visualisasi pola radiasi dapat dilakukan dengan mengambil data dari pengukuran level daya maupun pengukuran level medannya. Pada pola radiasi medan, apabila dinyatakan dalam pola yang ternormalisasi akan memiliki bentuk seperti persamaan (1).

$$
\mathrm{F}(\theta, \Phi)=\frac{\mathrm{E}(\theta, \Phi)}{\mathrm{E}(\theta, \Phi) \max }
$$

Pada pola radiasi daya dimana pointing vector memiliki komponen radial yang berbanding lurus dengan kuadrat magnitude kuat medan, maka bentuk normalisasinya adalah kuadrat dari pola medan yang sudah ternormalisasi seperti pada persamaan (2).

$$
\mathrm{P}(\theta, \Phi)=\operatorname{IF}(\theta, \Phi) \mathrm{I}^{2}
$$

Bentuk decibel dari kedua persamaan (1) dan (2) dapat dilihat pada persamaan (3) dan (4).

$>$ Untuk pola radiasi medan

$$
\mathrm{F}(\theta, \Phi) \mathrm{dB}=20 \log \mathrm{IF}(\theta, \Phi) \mathrm{I}
$$

$>$ Untuk pola radiasi daya

$$
\begin{aligned}
\mathrm{P}(\theta, \Phi) \mathrm{dB} & =10 \log \mathrm{P}(\theta, \Phi) \\
& =10 \log \mathrm{F}(\theta, \Phi)^{2} \\
& =20 \log \mathrm{F}(\theta, \Phi)
\end{aligned}
$$

Pengukuran pola radiasi antena dilakukan dengan cara meletakkan antena pemancar dan antena penerima dalam posisi sejajar pada jarak tertentu di dalam ruang anechoic chamber, set-up pengukuran terlihat pada Gambar1. Pengukuran daya radiasi antena pemancar dilakukan dengan cara memutar antena penerima pada setiap range tertentu dari $0^{\circ}$ sampai dengan $360^{\circ}$ dimana data level daya diukur pada setiap perputarannya.

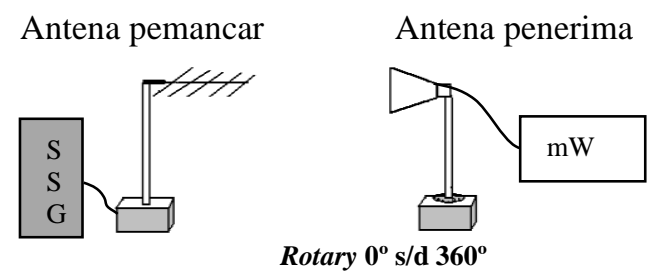

Gambar 1. Set-Up pengukuran
Pengukuran pola radiasi pada jarak benar-benar tak terhingga adalah suatu hal yang tidak mungkin. Maka untuk keperluan pengukuran ini, ada suatu daerah dimana medan yang diradiasikan oleh suatu antena sudah dapat dianggap sebagai tempat medan jauh apabila jarak antara kedua antena memenuhi ketentuan pada persamaan (5)

$$
r>\frac{2 D}{\lambda} \quad(r>D ; r>>)
$$

dimana:

$$
\begin{aligned}
& r=\text { jarak pengukuran } \\
& \mathrm{D}=\text { dimensi antena yang terpanjang } \\
& \lambda=\text { panjang gelombang }
\end{aligned}
$$

\subsection{Komunikasi Data Serial}

Komunikasi data serial yang digunakan adalah komunikasi data secara asinkron. Dimana clock tidak dikirimkan bersama data serial, melainkan dibangkitkan secara sendiri-sendiri baik pada sisi pengirim $(T x)$ maupun pada sisi penerima $(R x)$. Pada IBM PC kompatibel port serialnya termasuk jenis asinkron. Pada AT89S51, kecepatan pengiriman data (baud rate) dan fase clock pada sisi pemancar dan receiver harus sinkron. Untuk itu diperlukan sinkronisasi antara pemancar dan penerima. Hal ini dilakukan oleh bit 'Start' dan bit 'Stop'. Ketika saluran transmisi dalam keadaan idle, output UART adalah dalam keadaan logika '1'. Ketika transmitter ingin mengirimkan data, output UART akan diset lebih dulu ke logika '0' untuk waktu 1 bit. Sinyal ini pada penerima akan dikenali sebagai sinyal 'Start' yang digunakan untuk mensinkronkan fase clocknya sehingga sinkron dengan fase clock penerima. Selanjutnya data akan dikirimkan secara serial dari bit paling rendah (bit 0) sampai bit tertinggi. Selanjutnya akan dikirim sinyal 'Stop' sebagai akhir dari pengiriman data serial. Contoh pengiriman huruf ' $A$ ' dalam format ASCII (41 Heksa / 1000001 biner) tanpa bit paritas[5] dapat dilihat pada Gambar 2.

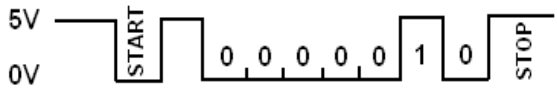

\section{Gambar 2. Pengiriman huruf 'A' tanpa bit paritas}

Kecepatan transmisi (baud rate) dapat dipilih bebas dalam rentang tertentu. Baud rate yang umum dipakai adalah 110, 135, 150, 300, 600, 1200, 2400, dan 9600 (bit/detik). Dalam komunikasi data serial, baud rate dari kedua alat yang berhubungan harus diatur pada kecepatan yang sama.

\subsection{Pengaksesan Port Serial Pada Visual Basic}

Pengaksesan port serial menggunakan kontrol MSComm yang telah disediakan Visual Basic. Kontrol MSComm menyediakan fasilitas komunikasi 
antara program aplikasi dengan port serial untuk mengirim atau menerima data melalui port serial [6].

\subsection{Komunikasi serial pada Spectrum Analyzer}

Komunikasi antara PC dengan spectrum analyzer adalah komunikasi serial dengan menggunakan RS232, dengan diagram koneksi seperti Gambar 3.
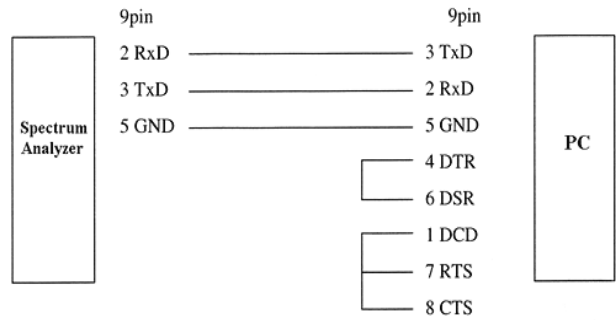

\section{Gambar 3. Koneksi RS-232 pada Spectrum analyzer dan PC[3]}

Pengiriman atau pengambilan data pada spectrum analyzer menggunakan kode ASCII. Format protokol untuk melakukan pengiriman atau pengambilan data seperti pada Gambar 4 [3]

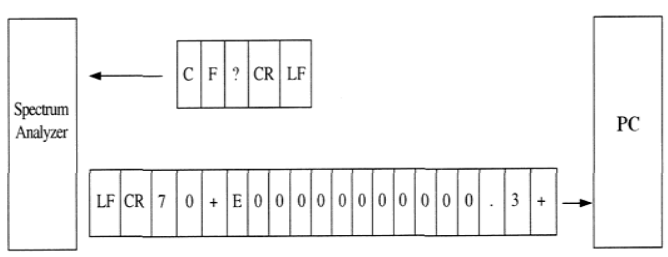

\section{Gambar 4. Protokol Komunikasi pada Spectrum Analyzer}

\section{PERANCANGAN SISTEM}

Perancangan sistem pengukuran pola radiasi meliputi pengukuran dengan visualisasi manual dan otomatis.

\subsection{Sistem Manual}

Pada sistem ini, pengaturan resolusi pengukuran dilakukan secara manual setiap $10^{\circ}$ dan data dicatat satu persatu setiap step pengukuran, kemudian dilakukan proses normalisasi dan digambar secara manual (visualisasi manual) atau dapat digambar menggunakan software secara terpisah. Hasil dari penggambaran sistem ini disebut sebagai visualisasi manual, dimana urutan proses visualisasi dapat dilihat pada Gambar 5.

\subsection{Sistem Otomatis}

Sistem otomatis ini dibuat untuk mengatasi kelemahan pada sistem manual, dimana pengaturan perputaran antena, pengambilan dan pengiriman data dilakukan secara otomatis dan diintegerasi dengan komputer dan dikendalikan dengan mikrokontroler. Proses kerja sistem otomatis dapat dilihat pada Gambar 6 .
Sedangkan set-up pengukuran sistem otomatis seperti terlihat pada Gambar 7.

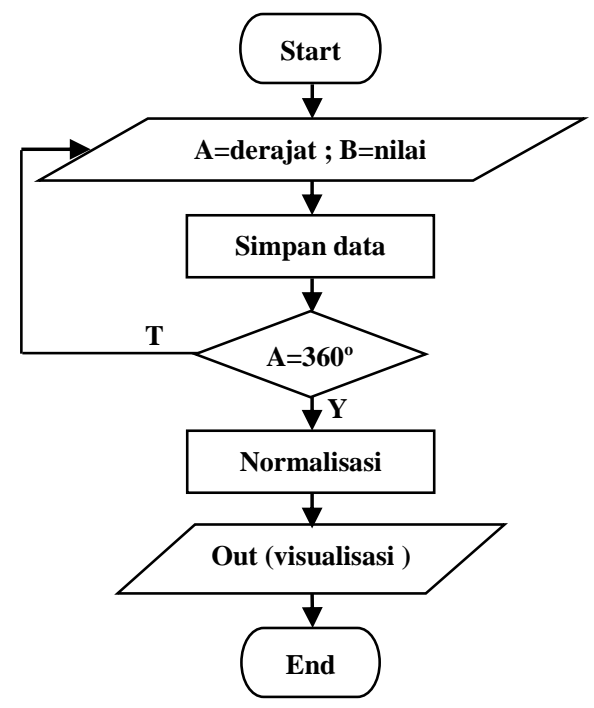

Gambar 5. Flowchart sistem manual

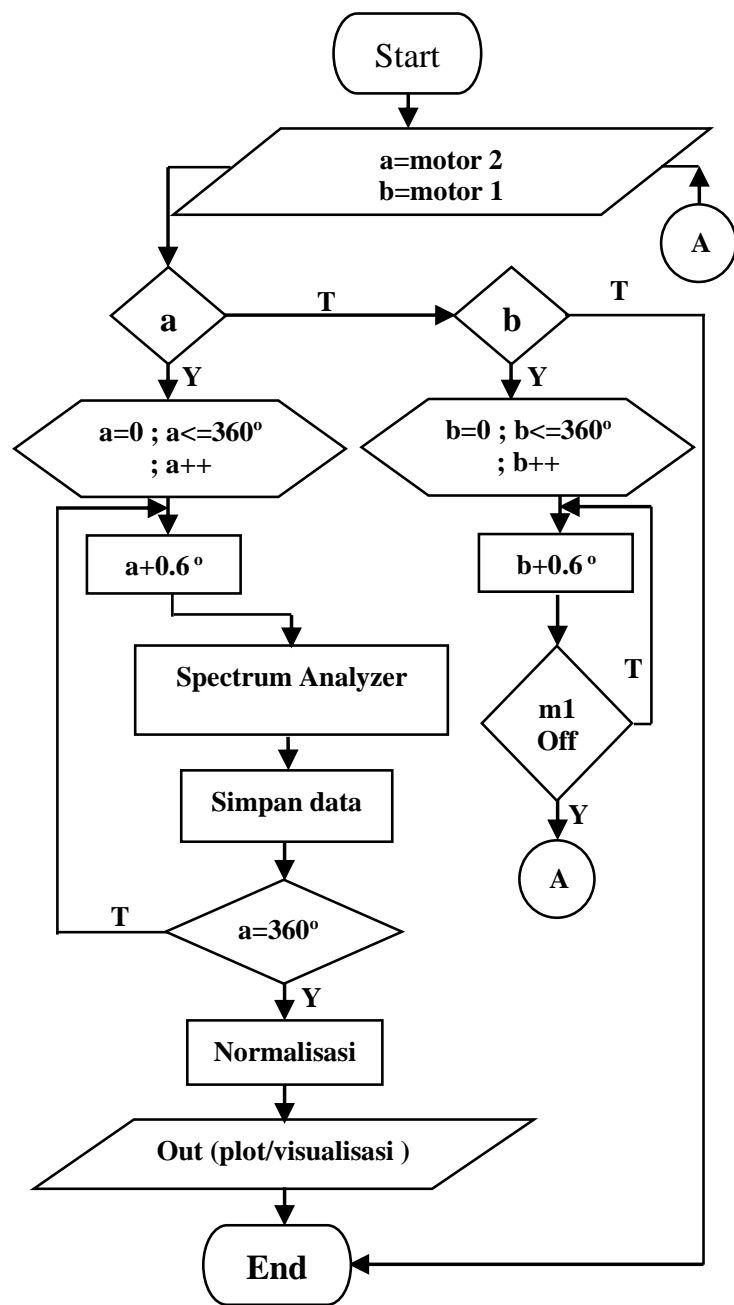

Gambar 6. Flowchart sistem otomatis 


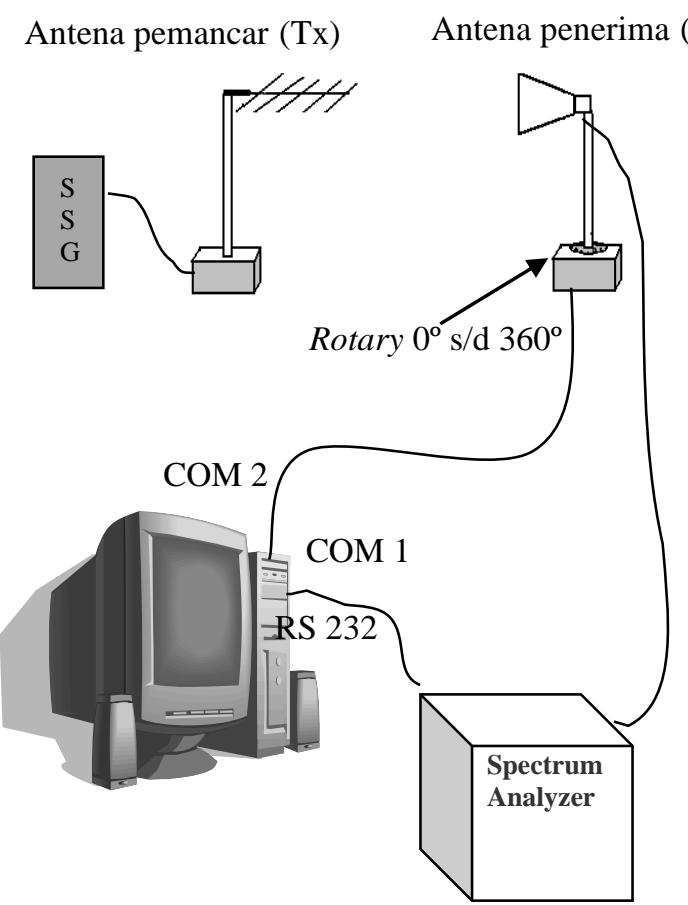

Gambar 7. Set-Up Pengukuran Sistem Otomatis

\section{IMPLEMENTASI DAN ANALISA SISTEM}

Pada bagian ini implementasi sistem akan dilakukan untuk visualisasi pola radiasi dari antenna horn dan antena dipole baik secara manual maupun otomatis. Kedua jenis antenna ini diletakkan sebagai antenna penerima, sedangkan antenna pemancar menggunakan Antena Log Periodic dengan sumber sinyal berasal dari standar signal generator (SSG). Bentuk fisik antena yang digunakan dalam pengukuran seperti terlihat pada Gambar 8 .

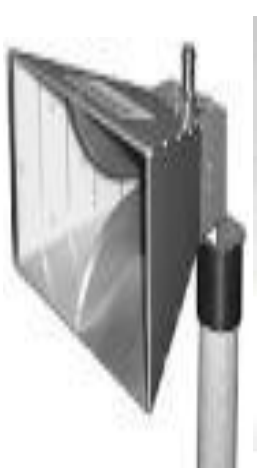

(a)

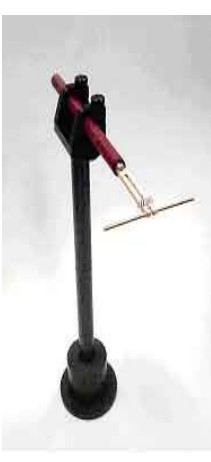

(b)

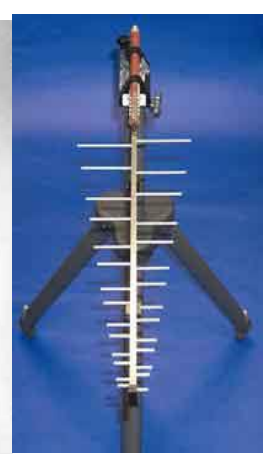

(c)
Gambar 8. Jenis Antena

(a) antena Horn, (b) Antena Dipole (c) Antena Log Periodic

\subsection{Implementasi Sistem Manual}

Sistem Manual diimplementasikan pada pengukuran dan visualisasi pola radiasi secara manual.

Pada sistem ini pengambilan sample data level daya diambil sebanyak 35 data, pengambilan data dilakukan pada setiap $10^{\circ}$ untuk perputaran dari $0^{\circ}$ sampai dengan $360^{\circ}$. Visualisasi dilakukan setelah proses normalisasi menggunakan software secara terpisah. Hasil visualisasi manual untuk pola radiasi bidang $\mathrm{E}$ antena horn dapat dilihat pada Gambar 9, sedang untuk bidang $\mathrm{H}$ seperti pada Gambar 10.

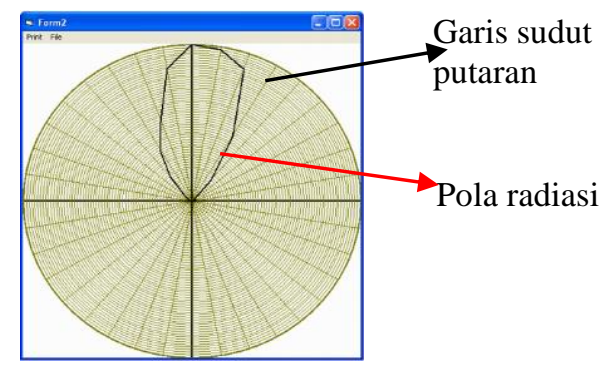

Gambar 9. Visualisasi pola radiasi antena Horn Bidang E

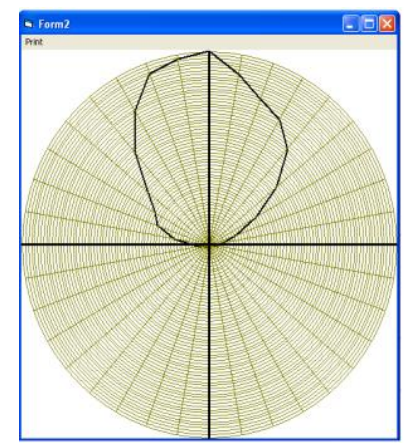

\section{Gambar 10. Visualisasi pola radiasi antena Horn Bidang $\mathbf{H}$}

Selain pada antena horn, sistem manual ini juga di implementasikan pada pengukuran antena dipole. Hasil pengukuran level daya dan bentuk visualisasi pola radiasi untuk antenna dipole dapat dilihat pada Gambar 11 untuk bidang E dan Gambar 12 untuk bidang $\mathrm{H}$.

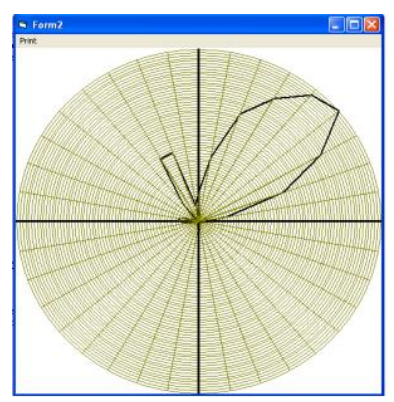

Gambar 11. Visualisai pola radiasi antena Dipole Bidang E 


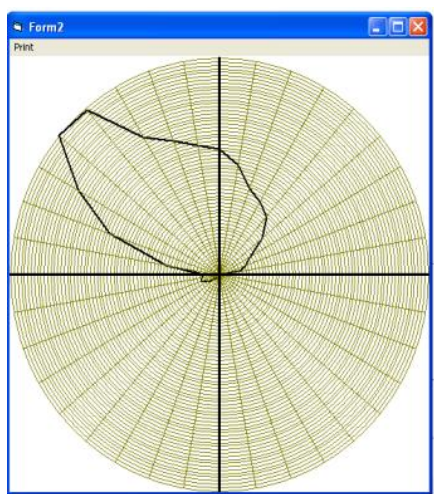

Gambar 12. Visualisasi pola radiasi antena Dipole Bidang $\mathbf{H}$

\subsection{Implementasi Sistem Otomatis}

Pada visualisasi Otomatis ini antenna penerima $(\mathrm{Rx})$ diletakkan pada alat tracking antenna yang terhubung dengan komputer melalui COM2. Tracking antenna akan berputar dari $0^{\circ} \mathrm{s} / \mathrm{d} 360^{\circ}$ dengan range derajat perputaran yang dapat ditentukan sendiri oleh user. Pilihan derajat yang diberikan pada visualisasi otomatis ini adalah sebesar $0.6^{\circ}, 1.2^{\circ}, 1.8^{\circ}, 3.0^{\circ}, 3.6^{\circ}$, $6.0^{\circ}, 7.2^{\circ}, 9.0^{\circ}$. Pada setiap perputarannya, spectrum analyzer akan mengukur nilai level daya. Hasil pembacaan level daya oleh spectrum analyzer yang dihubungkan pada komputer melalui COM1 secara otomatis tersimpan pada database. Prinsip kerja sistem otomatis dapat dilihat seperti Gambar 13.

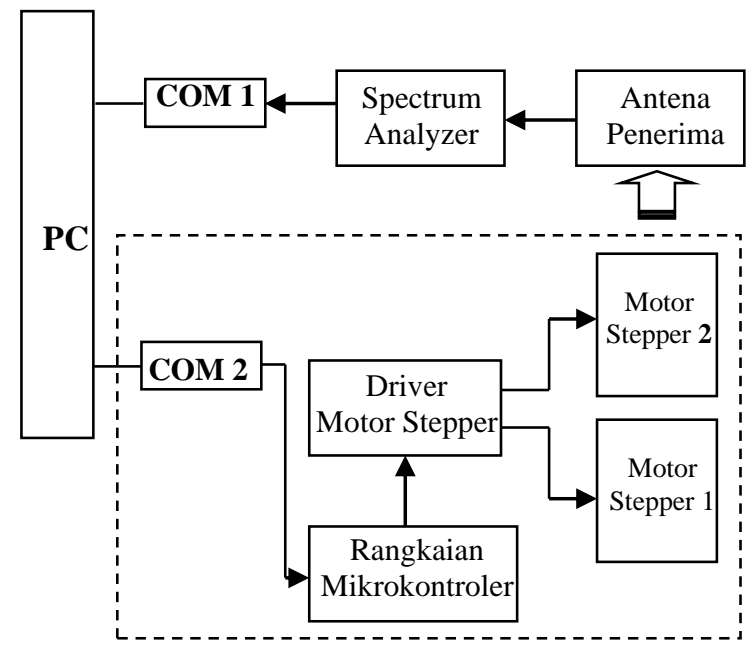

\section{Gambar 13. Diagram blok pengukuran pola} radiasi dengan tracking antena

Pada sistem ini sample data yang diperoleh sangat banyak sehingga data setiap stepnya dapat dimasukan secara langsung ke dalam database. Bentuk tampilan pada layar komputer seperti terlihat pada gambar 14 .

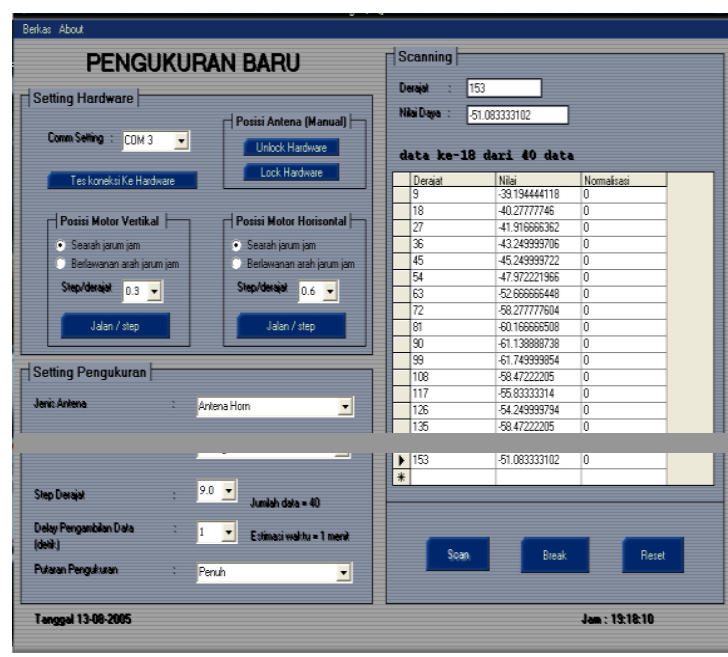

\section{Gambar 14 Tampilan form saat melakukan pengambilan data}

Sebelum dilakukan visualisasi, data dinormalisasi terlebih dahulu dengan menekan tombol normalisasi seperti pada Gambar 15. Pada saat itu maka proses perhitungan normalisasi dilaksanakan .

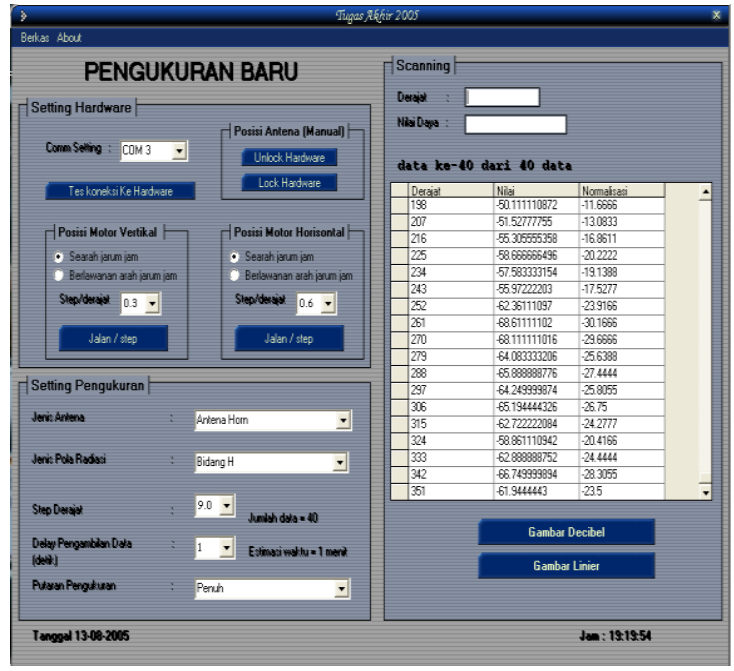

Gambar 15. Tampilan form setelah proses Normalisasi

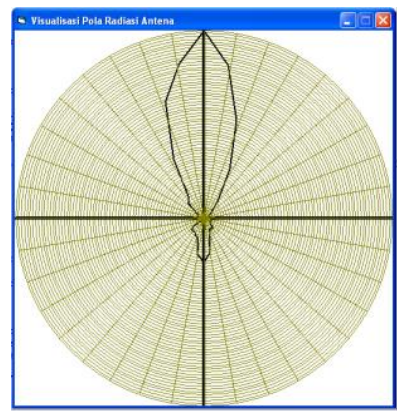

Gambar 16. Pola radiasi antena Dipole Bidang E 
Hasil visualisasi dapat dilihat dengan menekan tombol "Gambar Decibel" (apabila data yang diambil dalam satuan $\mathrm{dBm}$ ), dan tombol "Gambar Linier" (apabila data yang diambil dalam satuan Watt). Pada proses ini visualisasi dilakukan oleh software visualisasi secara otomatis. Supaya dapat dibangdingkan dengan hasil visualisasi manual, maka pada sistem otomatis dilakukan pengukuran dengan step $9^{\circ}$ dengan hasil untuk bidang E pada antena dipole dapat dilihat pada Gambar 16 dan untuk antena horn pada Gambar 17. Sedangkan visualisasi bidang $\mathrm{H}$ untuk antena dipole dapat dilihat pada Gambar 18 dan untuk antena horn seperti pada Gambar 19.

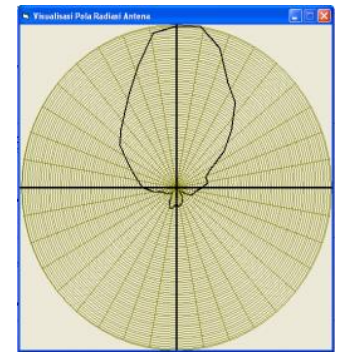

Gambar 17. Pola radiasi antena Horn Bidang E

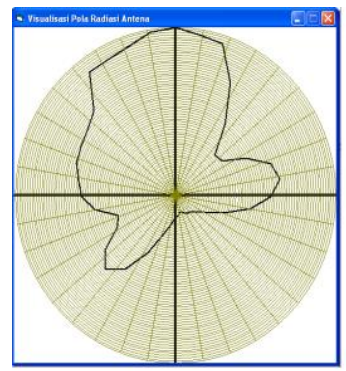

Gambar 18. Pola radiasi antena Dipole Bidang H

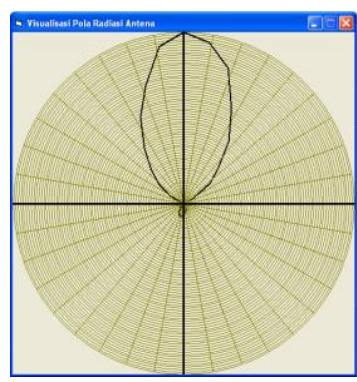

Gambar 19. Pola radiasi antena Horn Bidang H

\subsection{Analisa}

Dari hasil visualisasi manual maupun otamatis dapat dianalisis bahwa pada visualisasi dengan cara otomatis lebih baik daripada manual. Sebagai contoh dapat dibandingkan data hasil visualisasinya adalah sebagai berikut:

- Polaradiasi antenna Dipole bidang E visualisasi otomatis (gambar 16) tidak terdapat side loop dan pancaran radiasinya terfokus/terarah pada sudut $0^{\circ}$ atau posisi dimana antena $\mathrm{Tx}$ dan $\mathrm{Rx}$ saling berhadapan.

- Demikian juga untuk antena Dipole pada bidang H visualisasi otomatis (gambar 18) meskipun terdapat side loop, pancaran radiasinya lebih terfokus/terarah pada sudut $0^{\circ}$. Sehingga ketepatan sudut radiasi pada cara otomatis lebih baik daripada cara manual (gambar 12).

- Pola radiasi antenna Horn bidang $\mathrm{H}$ visualisasi otomatis (gambar 19) pancaran radiasinya lebih sempit atau terfokus/terarah pada sudut $0^{\circ}$. Dengan pancaran (beamwidth) yang lebih sempit, maka level daya yang diterima pada antena $\mathrm{Rx}$ akan lebih maksimal.

\section{KESIMPULAN}

Dari hasil implementasi sistem otomatis dan manual untuk penggambaran pola radiasi, dapat ditarik kesimpulan bahwa :

1. Hasil penggambaran pola radiasi secara manual baik bidang $\mathrm{E}$ maupun bidang $\mathrm{H}$ untuk antena horn dan dipole, posisi level daya maksimal (main loop) tidak selalu berada pada sudut $0^{\circ}$. Hal ini disebabkan karena adanya ketidak tepatan posisi antena selama proses pengambilan data.

2. Sedangkan sistem otomatis yang dibuat pada penelitian ini, menghasilkan penggambaran pola radiasi dengan ketepatan sudut yang lebih akurat, yaitu posisi main selalu berada pada sudut $0^{\circ}$ untuk semua bidang $\mathrm{E}$ dan $\mathrm{H}$.

3. Sistem visualisasi dengan software visual basic, dapat mempermudah komunikasi antara user dengan sistem otomatis yang dibuat (user friendly), sehingga dapat mempermudah mahasiswa dalam melaksanakan praktikum.

\section{DAFTAR PUSTAKA}

[1] John D. Kraus, Ronald J M, Antennas For All Applications Third Edition, Mc Graw Hill Book Company,2001

[2] Robert E. Collin, Antennas and Radiowave Propagation, Mc Graw Hill Book Company, 1985

[3] R3131 Spectrum Analyzer Operation Manual.

[4] Winemiller, Eric et al, Visual Basic 6 Database How - To, Sams Publishing, Indianapolis USA, 1998.

[5] Retna Prasetia, Catur edi Widodo, Teori dan Praktek Interfacing Port Paralel dan Port Serial Komputer dengan Visual basic 6.0, ANDI Yogyakarta, 2004.

[6] Halvorson Michael, Microsoft Visual Basic 6.0 Professional Step by Step, Second Edition , PT Elex Media Komputindo,2002

[7] Yeralan Sencer, Ahluwalia Ashithosh, Programming and Interfacing the 8051 Microcontroller, Addison-Publising Company, New York, 1995 